\title{
Effects of heat stress on serum progesterone in cyclic ewes and on progesterone and cortisol response to $\mathrm{ACTH}$ in ovariectomized ewes
}

\author{
M. A. Sheikheldin*†, B. E. Howland $†$ and W. M. Palmer* \\ Departments of *Animal Science and $\nmid$ Oral Biology, University of Manitoba, Winnipeg, Manitoba, \\ Canada R3E OW3
}

\begin{abstract}
Summary. The daily mean of serum progesterone in cyclic ewes $(N=5)$ as well as the profile characteristics of progesterone and cortisol in response to an acute single dose (5i.u./kg liveweight ${ }^{0.75}$ ) of adrenocorticotrophic hormone (ACTH) into ovariectomized ewes $(\mathrm{N}=4)$ was investigated during exposure to a constant thermoneutral temperature of $18 \pm 1^{\circ} \mathrm{C}$ or to a daily cyclic heat stress temperature of $18^{\circ} \mathrm{C}-35^{\circ} \mathrm{C}-18^{\circ} \mathrm{C}$, in an environmental chamber. Serum collected daily from the cyclic ewes was assayed for progesterone, while serum collected more frequently for $10 \mathrm{~h}$, on the 14 th day of exposure to the respective temperature, from the ovariectomized ewes was assayed for progesterone and cortisol by RIAs.

In cyclic ewes, heat stress increased the area under the daily progesterone curve $(P<0.09)$ but had no effect on progesterone concentration after the regression of the CL. In ovariectomized ewes, ACTH significantly elevated the response of both cortisol and progesterone $(r=0.75, P<0.001)$ within $10-15 \mathrm{~min}$ of injection. In the ovariectomized ewes and during heat stress, the responses of progesterone and cortisol to ACTH were characterized by an initial acute rise, a transient drop, a steep elevation and a gradual but prolonged decline. During thermoneutral temperatures, this biphasic response pattern was not observed. Since progesterone concentration in the ovariectomized ewes in response to heat stress or the ACTH injection were within the range of basal progesterone observed during the preovulatory period in cyclic ewes, our results give no evidence of a direct role for adrenal progesterone in depressing pituitary function in ewes exposed to a daily cyclic heat stress.
\end{abstract}

Keywords: heat stress; ewes; ACTH; progesterone; cortisol

\section{Introduction}

Exposure of cycling cows to chronic heat stress has been shown to be associated with elevated serum progesterone concentration (Abilay et al., 1975; Roussel et al., 1977) and depressed adrenal glucocorticoid secretion (Christison \& Johnson, 1972; Alvarez \& Johnson, 1973). Elevated progesterone values in sheep and cattle have been associated with depressed gonadotrophin release (Bjersing et al., 1972; Pant et al., 1977; Rahe et al., 1980). Therefore, the depressed luteinizing hormone surge in ewes exposed to chronic heat stress (Sheikheldin, 1987) could be due to elevated progesterone concentration. The literature is not clear regarding the source of the elevated progesterone with both the corpus luteum $(\mathrm{CL})$ and the adrenal cortex being possible sources. The reports of increased progesterone secretion after the injection of exogenous ACTH into ovariectomized (Benhaj \& Cooke, 1985) and ovariectomized-hypophysectomized (De Silva et al., 1983) ewes 
demonstrate the potential for adrenal secretion of progesterone. In support of the CL being the source of the elevated progesterone during heat stress, Wheeler \& Blackshaw (1986) have reported the possible involvement of the increased release of catecholamines during heat stress in the direct enhancement of progesterone secretion from the CL.

The present investigation was initiated (1) to determine the effect of daily cyclic heat stress on serum progesterone concentration in cycling ewes, (2) to elucidate the source of elevated progesterone in heat-stressed ewes, and (3) to determine whether heat stress modifies the adrenal response to an acute exogenous dose of adrenocorticotrophic hormone (ACTH).

\section{Materials and Methods}

\section{Experiment 1}

Animals. Five adult (liveweight $=65.2 \pm 1.9 \mathrm{~kg}$, mean \pm s.e.m.) cycling Suffolk ewes were used during the breeding season (October-December). Ewes were shorn (to fleece length of $<0.5 \mathrm{~cm}$ ) and exposed to a thermoneutral temperature of $18 \pm 1^{\circ} \mathrm{C}$ or to a daily cyclic heat stress temperature of $18^{\circ} \mathrm{C}-35^{\circ} \mathrm{C}-18^{\circ} \mathrm{C}$, by means of an enviromental chamber, $2.54 \mathrm{~m} \times 1.88 \mathrm{~m} \times 2.54 \mathrm{~m}$ (Coldstream, Fleming-Pedlar Ltd, Winnipeg, MB, Canada). The relative humidity $(55 \pm 2 \%)$ and photoperiod $(10 \mathrm{~h}$ light:14 h dark) were kept constant. Each ewe received a daily ration composed of $1.0 \mathrm{~kg}$ alfalfa pellets, $900 \mathrm{~g}$ barley and $1.0 \mathrm{~kg}$ hay. This daily allowance was given in two equal morning $(07: 00 \mathrm{~h})$ and afternoon $(15: 00 \mathrm{~h})$ portions. The animals were left loose in the chamber and were fed in a common feeding trough. The oestrous cycle was synchronized before exposure with two injections of prostaglandin F-2 $\alpha$ (cloprostenol: ICI Pharma, Mississauga, Ontario, Canada) given 10 days apart. The ewes were studied for two consecutive cycles. The first oestrous cycle was at Thermoneutral temperature and was followed by the second at heat stress. The switch of the chamber temperature from 18 to $35^{\circ} \mathrm{C}$ was done at $12: 00 \mathrm{~h}$ on Day 17 of the oestrous cycle.

Sampling procedures. Daily jugular blood $(7.0 \mathrm{ml})$ was collected by vacutainers and the serum was stored at $-20^{\circ} \mathrm{C}$ until the estimation of progesterone using radioimmunoassay (RIA) procedures.

\section{Experiment 2}

Animals. Four long-term ( $>5$ months) ovariectomized (liveweight $=85.2 \pm 2.2 \mathrm{~kg}$, mean \pm s.e.m.) ewes of the Suffolk breed were used. The animals were also shorn and exposed to temperature, relative humidity and photoperiod setting identical to those in Exp. 1, using the same environmental chamber. Each ewe received the same daily ration as did the ewes in Exp. 1, but was fed individually in metabolism crates. Ewes were exposed to alternate 2-week periods of thermoneutral temperature and cyclic heat stress and in each temperature 2 ewes received an acute single dose ( 5 i.u. per $\mathrm{kg}$ liveweight ${ }^{0.75}$ ) of adrenocorticotrophic hormone (ACTH) (porcine-ACTH1-39: Sigma Chemical Co., St Louis, MO, U.S.A.) prepared in $5 \mathrm{ml}$ saline $(0.154 \mathrm{M}-\mathrm{NaCl})$, while the remaining 2 ewes were given saline only. There was a 15-day rest period before each temperature exposure. During the rest periods, the chamber temperature was kept at $18 \pm 1^{\circ} \mathrm{C}$.

Sampling procedures. Ewes were subjected to intensive blood sampling sessions between 07:00 and 17:00 h on Day 14 of each treatment period, using jugular catheters inserted on Day 13. Starting at $07: 00 \mathrm{~h}$, samples were taken at 15-min intervals for $2 \mathrm{~h}$ before the injection. At 09:00 h ACTH or saline was given as a single dose through the jugular catheter (total volume $=5 \mathrm{ml}$ ). Further samples were collected at $0,5,10,15,20,25$ and $30 \mathrm{~min}$ after the injection and thereafter at $15-\mathrm{min}$ intervals until $17: 00 \mathrm{~h}$. Serum was harvested and stored at $-20^{\circ} \mathrm{C}$ until the estimation of progesterone and cortisol using RIA procedures.

\section{Hormone assays}

Chemicals and reagents used, unless specified, were all of analytical grade. Buffers were prepared and used fresh, or kept at $4 \cdot 0^{\circ} \mathrm{C}$ and changed every 10 days. The hormone standards and the unknowns were run in triplicate and duplicate, respectively. All samples from an individual ewe were estimated in the same run. Assay tubes were counted for $4.0 \mathrm{~min}$ in a liquid scintillation counter (Rackbeta $\$ 1217$ : LKB, Wallac OY, Finland), fitted with a microcomputer that was programmed to calculate unknown concentrations from the standard curves using spline-functions (Wold, 1974).

Progesterone. Progesterone was estimated according to the assay originally described by Abraham et al. (1971) and modified by Yuthasastrakosol et al. (1974), with the following exceptions: (1) both the standard and the unknowns were simultaneously extracted; (2) during the separation step an ordinary charcoal solution ( $375 \mathrm{mg}$ 
washed charcoal/100 $\mathrm{ml}$ assay buffer) was used instead of the dextran-coated charcoal; and (3) after the addition of charcoal the assay tubes were incubated at $4^{\circ} \mathrm{C}$ for $10 \mathrm{~min}$, rather than $20 \mathrm{~min}$.

The progesterone standard (4-pregnen-3,20-dione: Steraloid Inc., Wilton, NH, USA) was prepared in charcoalstripped serum from an ovariectomized ewe which contained $<43 \cdot 2 \pm 1.9 \mathrm{pg}$ progesterone $/ \mathrm{ml}$ (20 assays). Labelled progesterone $\left(\left[{ }^{3} \mathrm{H}\right]\right.$ progesterone: New England Nuclear, Boston, MA, U.S.A.) was prepared in the assay buffer to yield $34000-37000$ c.p.m. per $100 \mu \mathrm{l}$ per tube. Progesterone antibody provided by Dr N. C. Rawlings (Department of Veterinary Physiological Sciences, W.C.V.M., University of Saskatchewan, Saskatoon, Saskatchewan, Canada), cross-reacted at $0.47 \%, 0.04 \%, 0.01 \%$ and $0.01 \%$ with cholesterol, testosterone, hydrocortisone and oestradiol- $17 \beta$, respectively. The antibody was used at a dilution of 1:5000.

Samples were assayed at volumes of $0 \cdot 5-1 \cdot 0 \mathrm{ml}$ per tube. The efficiency of progesterone extraction was $78.0 \%$ ( 26 assays). Total binding of the antibody was $41.7 \%$ and the non-specific binding was $2 \cdot 2 \%$ (Rodbard et al., 1970; Abraham, 1974). The sensitivity of the assay at $95 \%$ binding was $15.4 \mathrm{pg}$ per tube (Eikins, 1974). When ewe serum pools containing $0.15,2.50$ and $11.20 \mathrm{ng} / \mathrm{ml}$ were assayed repeatedly, the intra-assay coefficients of variation (CVs) (Rodbard et al., 1968) were $7.4 \%, 3.3 \%$ and $6.0 \%$, respectively. The corresponding values for the inter-assay CVs were $15 \cdot 8 \%, 4 \cdot 6 \%$ and $6 \cdot 4 \%$, respectively.

Cortisol. The cortisol RIA was a modification of the competitive protein-binding assay previously described by Rawlings \& Ward (1978). The assay buffer (phosphate buffer saline, PBS, containing $5.38 \mathrm{~g}$ monobasic sodium phosphate, $8.66 \mathrm{~g}$ anhydrous dibasic sodium phosphate, $9.0 \mathrm{~g}$ sodium chloride, $1.0 \mathrm{~g}$ sodium azide and $1.0 \mathrm{~g}$ gelatin in 1.0 litre deionized distilled water, $\mathrm{pH}=7.4$ ) was identical to the one used in the progesterone assay (Yuthasastrakosol et al., 1974). Cortisol standard (hydrocortisone: Steraloid Inc.) was prepared in charcoal-stripped serum from an ovariectomized ewe and contained $<106 \pm 11 \mathrm{pg}$ cortisol/ml (16 assays). Labelled cortisol ([ $\left.{ }^{3} \mathrm{H}\right]$ hydrocortisone; New England Nuclear), was prepared in the assay buffer to give 28000 d.p.m. (6000 c.p.m.) in a total volume of $200 \mu l$ $(\sim 60 \mathrm{pg}$ per tube).

The antibody provided by Dr N. C. Rawlings (W.C.V.M., University of Saskatchewan) cross-reacted at $10 \%$ with progesterone, but at $<1.0 \%$ with dehydroepiandrosterone, pregnenolone, testosterone, oestradiol-17 $\beta$, oestradiol$17 \alpha$ or cholesterol. The antibody was prepared in the assay buffer and used at a dilution of 1:2500.

Since the adrenal glands of the ovariectomized ewe secrete moderate quantities of progesterone, progesterone was extracted from all samples with petroleum ether (Grade $\$ 20-40^{\circ} \mathrm{C}, \mathrm{J}$. T. Baker Chemical Co., Phillipsburg, NJ, U.S.A.) before cortisol assay. All the extraction steps were performed at $4^{\circ} \mathrm{C}$ and $1.0 \mathrm{ml}$ petroleum ether was added to $(12 \times 75)$ culture tubes containing $200 \mu$ lof the standard (triplicates) or the unknowns (duplicates). The tubes were stoppered, vortexed gently $\left(20 \mathrm{sec}\right.$ ) and kept at $-20^{\circ} \mathrm{C}$ for $1.0 \mathrm{~h}$. The supernatant (containing progesterone) was then aspirated. Subsequently, $1.5 \mathrm{ml}$ absolute alcohol were added to all tubes. After vortexing $(60 \mathrm{sec})$ and centrifugation (at $1000 \mathrm{~g}$ ) for $10 \mathrm{~min}$, the supernatant layer was decanted into a new set of $(12 \times 75)$ tubes and alcohol was evaporated in a water bath $\left(a t 60^{\circ} \mathrm{C}\right.$ ) under a gentle flow of nitrogen. After this final extraction, $200 \mu \mathrm{l}$ cortisol antibody were pipetted to all tubes, except the tubes for non-specific binding into which an equivalent volume of buffer was pipetted. Then $200 \mu$ l of the cortisol trace were added to all tubes, including the NSB tubes. The subsequent steps of the assay were as described for the progesterone assay.

The efficiency of progesterone removal by petroleum ether was estimated to be $85.5 \%$ ( 6 assays). Total binding of the antibody was $24.0 \%(n=23)$ with non-specific binding of $0.8 \%$. The sensitivity of the assay at $95 \%$ binding was $46.5 \mathrm{pg}$ per tube. The intra-assay CVs of ewe serum pools containing $10.7,20.5$ and $32.3 \mathrm{ng}$ cortisol $/ \mathrm{ml}$ were $9 \cdot 3 \%, 6 \cdot 2 \%$ and $5 \cdot 7 \%$, respectively. The corresponding values for the inter-assay CVs were $11 \cdot 1 \%, 7 \cdot 6 \%$ and $11.7 \%$, respectively.

\section{Statistical analysis}

All estimates of hormone concentrations made on frequently collected samples were initially subjected to analysis by the Pulsar programme (Merriam \& Wachter, 1982), which identifies baselines, amplitudes, peaks, frequencies, duration of peaks and interpeak intervals. This programme eliminates circadian and long-term trends by using Robust Locally Weighted Regression Analysis (Cleveland, 1979). Hormone peaks were identified using the multiples of the intra-assay standard deviations (s.d.) by which a pulse should rise above the preceding nadir point to be identified as a peak (defined in the Program as ' $G$ Values'). These values were selected as 5.5, 4.5, 4.0, 3.5 and 3.0 times the s.d. when a peak is comprised of $1,2,3,4$ and 5 points, respectively. Subsequently, the data were subjected to analyses of variance (ANOVA) using computer programs according to the software packages provided by Statistical Analysis Systems (SAS Institute, Inc. 1982). All hormone data were transformed (log base 10) before the analysis. Progesterone data from cyclic ewes were analysed by arbitrarily dividing the oestrous cycle into follicular (Days 1-4), early luteal (Days 5-8), mid-luteal (Days 9-12) and late luteal (Days 13-16) phases. In addition, the area under the daily progesterone curve was calculated as described by Howland et al. (1978). Comparisons between treatments and temperatures were made using $2 \times 2 \times 4$ factorial design (Snedecor \& Cochran, 1967). The two factors were treatment (ACTH vs saline) and temperature $\left(18 v s 35^{\circ} \mathrm{C}\right)$; ewes were considered as blocks. Duncan's multiple range test was used to compare differences in progesterone values between phases of the oestrous cycle. Whenever necessary, simple correlation coefficients were calculated according to Snedecor \& Cochran (1967). A simple $t$ test was used to determine differences between hormone means before and after the injection of saline or ACTH. 


\section{Results}

\section{Experiment 1}

Ambient temperature $\left(T_{\text {ambient }}\right)$. There were minimal fluctuations in the $24-\mathrm{h} \mathrm{T}_{\text {ambient }}$ during exposure to thermoneutral temperature $\left(18 \cdot 13 \pm 0 \cdot 10^{\circ} \mathrm{C}\right)$. However, during exposure to cyclic heat stress, $T_{\text {ambient }}$ rose progressively from $21 \cdot 3 \pm 0.2^{\circ} \mathrm{C}$ at $07: 00 \mathrm{~h}$ to $26.4 \pm 0.3^{\circ} \mathrm{C}$ at $09: 00 \mathrm{~h}$, to $30 \cdot 2 \pm 0 \cdot 2^{\circ} \mathrm{C}$ at $11: 00 \mathrm{~h}$ and reached a peak of $33.8 \pm 0 \cdot 2^{\circ} \mathrm{C}$ at 14:00 $\mathrm{h}$. After this peak at 14:00 h, $\mathrm{T}_{\text {ambient }}$ was stable until $15: 00 \mathrm{~h}$ and then fell steeply to $<22^{\circ} \mathrm{C}$ within $2 \mathrm{~h}$ and remained at this temperature until the early morning hours.

Progesterone concentration in cycling ewes. Progesterone concentration during the oestrous cycle is depicted in Fig. 1. Mean progesterone values tended to be elevated between Days 2 and 11 of the cycle during cyclic heat stress compared to thermoneutral temperature. Analysis of variance of the area under the daily progesterone curve showed greater area during heat stress $(P<0.09)$. The removal of one ewe which had lower progesterone during heat stress, resulted in a significant

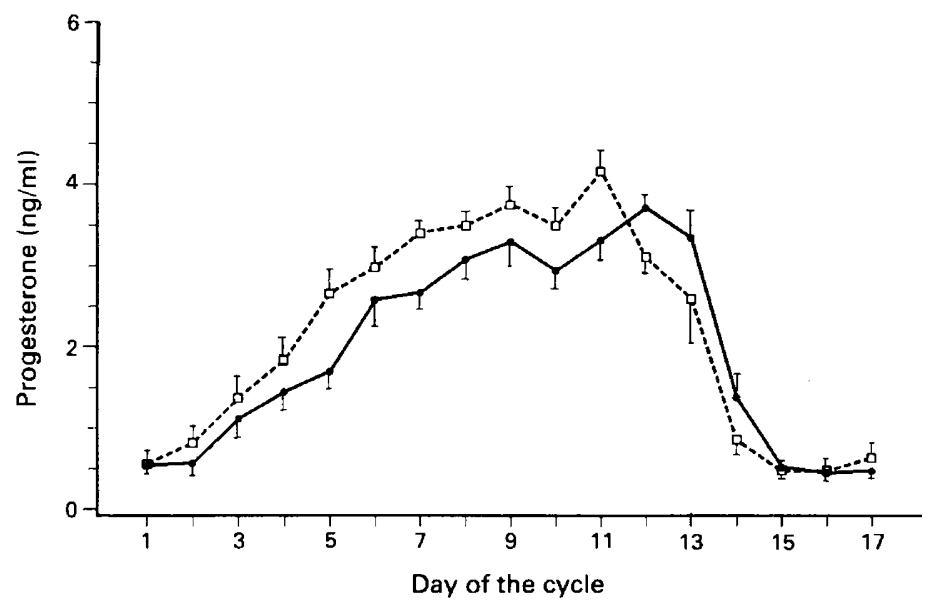

Fig. 1. Changes in mean $( \pm$ s.e.m.) concentration of daily serum progesterone in cycling ewes $(\mathrm{N}=5)$ during exposure to thermoneutral temperature $(\Theta)$ or during daily cyclic heat stress $(\square)$.

Table 1. Progesterone concentrations $(\mathrm{ng} / \mathrm{ml})$ in the follicular (Days 1-4), early luteal (Days 5-8), mid-luteal (Days 9-12) and late luteal (Days 1316) phases of the oestrous cycle in ewes exposed to a thermoneutral temperature or to a daily cyclic heat stress

\begin{tabular}{lcc}
\hline \multirow{2}{*}{$\begin{array}{l}\text { Phase of } \\
\text { cycle }\end{array}$} & \multicolumn{2}{c}{ Temperature } \\
\cline { 2 - 3 } & Thermoneutral & Heat stress \\
\hline Follicular & $0.92 \pm 0 \cdot 13^{\mathrm{a}}$ & $1 \cdot 15 \pm 0 \cdot 17^{\mathrm{b}}$ \\
Early luteal & $2 \cdot 52 \pm 0 \cdot 17^{\mathrm{c}}$ & $3 \cdot 15 \pm 0 \cdot 15^{\mathrm{d}}$ \\
Mid-luteal & $3.33 \pm 0 \cdot 14^{\mathrm{de}}$ & $3.64 \pm 0 \cdot 16^{\mathrm{e}}$ \\
Late luteal & $1.43 \pm 0.29^{\mathrm{b}}$ & $1 \cdot 10 \pm 0 \cdot 26^{\mathrm{ab}}$ \\
\hline
\end{tabular}

Values are mean \pm s.e.m. for 5 ewes.

a-e Means having the same superscript do not differ $(P>0.05)$. 

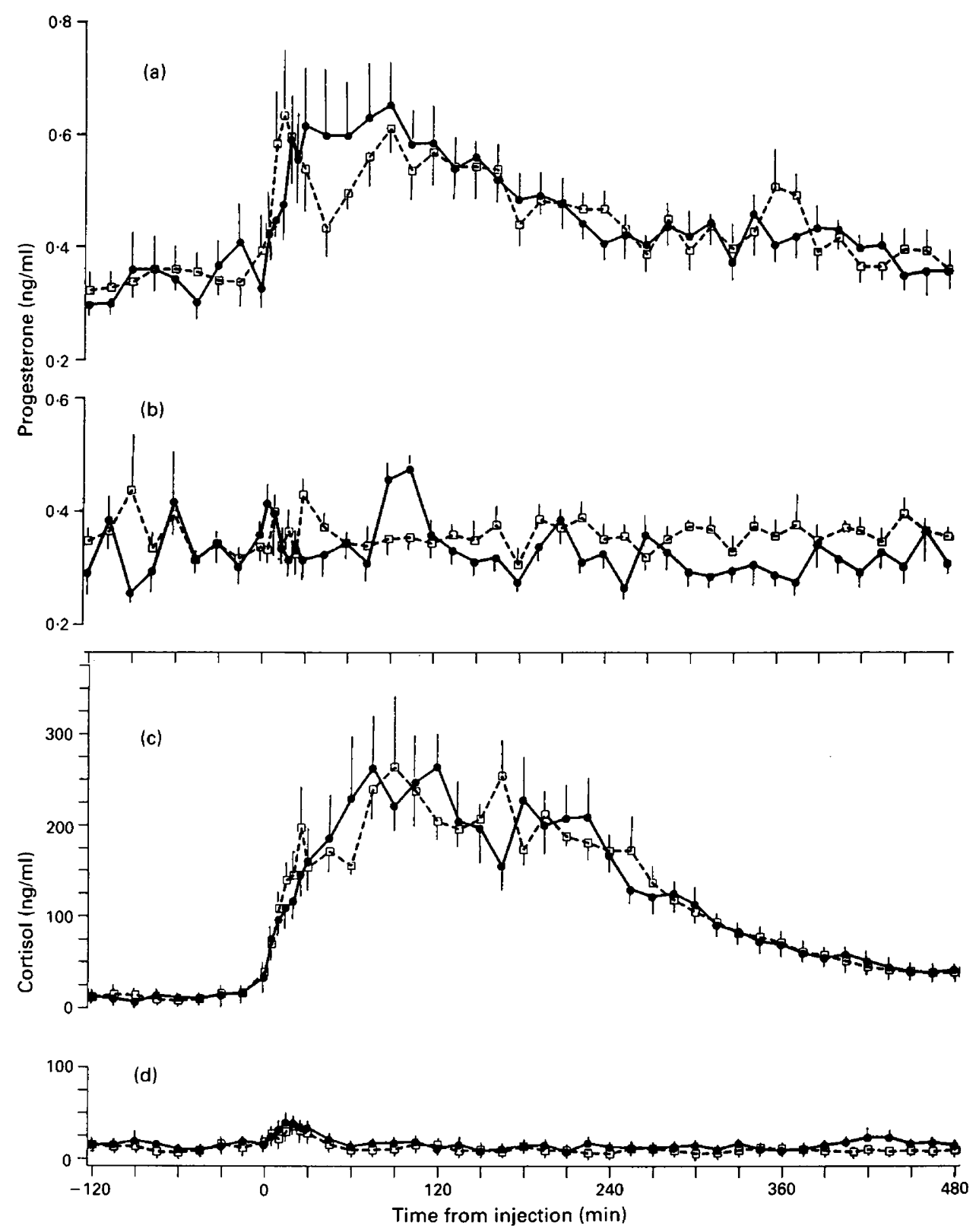

Fig. 2. Changes in mean ( \pm s.e.m.) concentrations of serum progesterone $(a, b)$ and cortisol $(c, d)$ in ovariectomized ewes $(\mathrm{N}=4)$ in response to injection of ACTH $(a, c)$ or saline $(b, d)$ (at time 0 ) during exposure to thermoneutral temperature $(O)$ or during daily cyclic heat stress $(\square)$.

difference between temperatures $(P<0 \cdot 01)$. Analysis of variance of the oestrous cycle by phase revealed significant differences between phases $(P<0.001)$ and also temperature $\times$ phase interaction $(P<0.01)$. Duncan's multiple range test showed that progesterone was elevated in the follicular and early-luteal phases during heat stress compared to the corresponding phases during 
thermoneutral temperature $(P<0.05)$ (Table 1). Progesterone values after regression of the CL (late luteal phase) were comparable between the two temperatures.

\section{Experiment 2}

Ambient temperature. The $\mathrm{T}_{\text {ambient }}$ during exposures to thermoneutral or high temperature was similar to that in Exp. 1.

Progesterone response to the injections of saline or $A C T H$. The progesterone profiles before and after the injections are shown in Fig. 2. Progesterone concentrations in the intervals before and after saline were comparable (Fig. 2b). However, mean progesterone concentration tended to be more variable during exposure to thermoneutral temperature.

Serum progesterone profiles before the injection of ACTH were comparable to those observed in the same interval before saline injection (Fig. 2a). After the injection of ACTH during thermoneutral temperature, progesterone rose acutely to values significantly higher $(P<0.05)$ than the preinjection concentration within $15 \mathrm{~min}(0.48 \pm 0.05 \mathrm{ng} / \mathrm{ml})$ and further increased to a peak of $0.62 \pm 0.05 \mathrm{ng} / \mathrm{ml}$ at $30 \mathrm{~min}$ after injection. Values continued to fluctuate reaching a maximum at 75 min after ACTH and then declined gradually over the remainder of the sampling period. Mean progesterone value at $75 \mathrm{~min}$ after ACTH during thermoneutral temperature was higher than the preinjection concentration $(P<0.05)$, but was comparable to the peak at 30 min after injection.

Progesterone secretion after ACTH during heat stress revealed a biphasic response. Heat stress enhanced adrenal progesterone, resulting in a peak at $15 \mathrm{~min}$ after ACTH injection. Then, instead of the elevated progesterone values which were observed during the corresponding period at $18^{\circ} \mathrm{C}$, concentration declined during the next $30 \mathrm{~min}$ to a nadir value at $45 \mathrm{~min}$ after ACTH. After these low concentrations progesterone rose to a second peak which was comparable in magnitude to the first. This second peak was followed by a gradual but a prolonged declining trend to the end of the sampling period.

Analysis of variance of progesterone concentration by hourly periods $(n=9)$ after the injection of saline or ACTH revealed significant differences between treatments $(P<0.05)$ and periods $(P<0.01)$ as well as treatment $\times$ period $(P<0.01)$ and temperature $\times$ period $(P<0.05)$ interactions.

Analysis of variance of the Pulsar data for the profile characteristics of progesterone in response to saline or ACTH showed no differences between treatments or temperatures and no interactions in the characteristics measured, except for the mean basal progesterone (Table 2), which was significantly elevated by ACTH $(P<0 \cdot 05)$.

Cortisol response to the injections of saline or $A C T H$. The cortisol profiles were analysed in a fashion similar to those of progesterone. Profiles before and after saline injection were similar between temperatures (Fig. 2d). Irrespective of the temperature, an abrupt rise in cortisol followed the injection of saline. However, values returned to preinjection concentration within $60 \mathrm{~min}$.

The cortisol means before ACTH injection were not significantly different between temperatures (Fig. 2c). After the injection an acute increase $(P<0.05)$ in cortisol was detectable within $10 \mathrm{~min}$, irrespective of the temperature. During thermoneutral temperature exposure there was an acute steady rise reaching a peak at $75 \mathrm{~min}$ after injection. The concentrations after the peak showed some fluctuation in amplitudes with a tendency to fall gradually over time in fashion similar to that of progesterone during the same temperature $(r=0.75, P<0.001)$.

During heat stress, cortisol was elevated in response to ACTH at 10-25 min after the injection. However, this was followed by a transient decline, 10-25 min after ACTH. This drop was similar to the one observed for progesterone after the injection of ACTH. Thereafter, cortisol concentration rose to values seen during the thermoneutral temperature. Cortisol response to ACTH during heat stress therefore also showed a biphasic trend which was similar to that seen for progesterone $(r=0 \cdot 50, P<0 \cdot 001)$. 
Table 2. Profile characteristics of progesterone and cortisol in ovariectomized ewes treated with saline or ACTH during exposure to thermoneutral temperature or daily cyclic heat stress

\begin{tabular}{|c|c|c|c|c|}
\hline & \multicolumn{4}{|c|}{ Treatment } \\
\hline & \multicolumn{2}{|c|}{ Saline } & \multicolumn{2}{|c|}{ ACTH } \\
\hline & $\begin{array}{l}\text { Thermoneutral } \\
\text { temperature }\end{array}$ & Heat stress & $\begin{array}{l}\text { Thermoneutral } \\
\text { temperature }\end{array}$ & Heat stress \\
\hline \multicolumn{5}{|l|}{ Progesterone } \\
\hline $\begin{array}{l}\text { Mean conc.* } \\
(\mathrm{ng} / \mathrm{ml})\end{array}$ & $0 \cdot 27 \pm 0 \cdot 02$ & $0 \cdot 31 \pm 0 \cdot 01$ & $0.37 \pm 0.02$ & $0.38 \pm 0.03$ \\
\hline $\begin{array}{l}\text { Pulse amplitude } \\
(\mathrm{ng} / \mathrm{ml})\end{array}$ & $0 \cdot 12 \pm 0 \cdot 01$ & $0.11 \pm 0.01$ & $0.14 \pm 0.02$ & $0.13 \pm 0.01$ \\
\hline $\begin{array}{l}\text { Pulse frequency } \\
\text { (per min) }\end{array}$ & $0.025 \pm 0.001$ & $0.022 \pm 0.002$ & $0.021 \pm 0.001$ & $0.021 \pm 0.001$ \\
\hline $\begin{array}{l}\text { Duration of pulse peak } \\
\text { (min) }\end{array}$ & $25.93 \pm 2.02$ & $31 \cdot 52 \pm 4 \cdot 72$ & $33.09 \pm 2.90$ & $32.67 \pm 2.74$ \\
\hline $\begin{array}{l}\text { Interpeak interval } \\
\quad(\min )\end{array}$ & $41.77 \pm 2.81$ & $47 \cdot 35 \pm 4 \cdot 12$ & $48.00 \pm 2.64$ & $49.81 \pm 3.04$ \\
\hline \multicolumn{5}{|l|}{ Cortisol } \\
\hline $\begin{array}{l}\text { Mean conc. } \dagger \\
\quad(\mathrm{ng} / \mathrm{ml})\end{array}$ & $8 \cdot 78 \pm 0.31$ & $7.68 \pm 1.44$ & $77.20 \pm 7.84$ & $86 \cdot 15 \pm 10 \cdot 05$ \\
\hline $\begin{array}{l}\text { Pulse amplitude* } \\
\text { (ng/ml) }\end{array}$ & $19.53 \pm 2.24$ & $10 \cdot 40 \pm 1.42$ & $57.98 \pm 15 \cdot 15$ & $59.98 \pm 11.41$ \\
\hline $\begin{array}{l}\text { Pulse frequency } \\
\text { (per min) }\end{array}$ & $0.017 \pm 0.002$ & $0.020 \pm 0.001$ & $0.022 \pm 0.001$ & $0.022 \pm 0.002$ \\
\hline $\begin{array}{l}\text { Duration of puise peak } \\
\text { (min) }\end{array}$ & $41 \cdot 20 \pm 4 \cdot 72$ & $32.25 \pm 1.47$ & $29 \cdot 18 \pm 1 \cdot 63$ & $30 \cdot 60 \pm 2 \cdot 35$ \\
\hline $\begin{array}{l}\text { Interpeak interval } \\
(\mathrm{min})\end{array}$ & $62.35 \pm 5.90$ & $51 \cdot 83 \pm 3 \cdot 40$ & $48.00 \pm 1.95$ & $48.73 \pm 4.01$ \\
\hline
\end{tabular}

Values are mean \pm s.e.m. for 4 ewes.

*Treatment effect, $P<0.05$.

†Treatment effect, $P<0 \cdot 01$.

The analysis of variance of the concentration of cortisol in response to the injection of saline or ACTH by hourly periods $(n=9)$ showed significant differences between treatments $(P<0.001)$ and periods $(P<0.01)$ as well as a significant interaction between treatment and period $(P<0.01)$.

The analysis of variance of the Pulsar characteristics of cortisol profiles also showed significant elevation in mean basal cortisol in ACTH-treated ewes $(P<0.01)$ (Table 2). In addition, the cortisol pulse amplitude was greater in ACTH-treated animals $(P<0.05)$.

\section{Discussion}

The maximum temperature treatment used in this study was similar to the maximum but constant temperature settings used by Christison \& Johnson (1972) to induce heat stress in cattle. In the present study cyclic heat stress was used. Exposure of cycling ewes to cyclic heat stress has been shown to be accompanied by significant changes in rectal temperature and respiration rate and associated with dramatic changes in the release profiles of prolactin when $T_{\text {ambient }}$ rose above 31$33^{\circ} \mathrm{C}$ (Sheikheldin, 1987). Therefore, the ewes in this study were assumed to be heat-stressed to the same magnitude as the ewes in that previous study. Abilay et al. (1975) have used a constant temperature at $33.5^{\circ} \mathrm{C}$ to induce the elevation of progesterone in cycling cows. However, despite the usefulness of the exposure of animals to constant temperature settings in answering specfic questions related to hyperthermia, diurnal fluctations are more representative of the natural conditions. 
By adopting a daily cyclic $T_{\text {ambient }}$, the aim of this study was to reduce the severity of physiological and hormonal disturbances which occur when animals are exposed to constant temperatures above their thermocomfort zones.

The larger area under daily progesterone in the cycling ewes during cyclic heat stress in this investigation agrees with a previous report of increased progesterone in cyclic cows exposed to a constant heat stress of $33.5^{\circ} \mathrm{C}$ (Abilay et al., 1975). The current results clearly indicate that the progesterone response to cyclic heat stress in cycling ewes occurred mainly in the presence of an active $\mathrm{CL}$ in the ovary. Progesterone concentration after regression of the $\mathrm{CL}$ was not affected by temperature. A similar observation was made in cows when progesterone concentration on the day of oestrus (after regression of the $\mathrm{CL}$ ) was not different in animals kept at $33.5^{\circ} \mathrm{C}$ and in those kept at $18 \cdot 2^{\circ} \mathrm{C}$ (Abilay et al., 1975).

The lack of temperature effect on cortisol values in saline-treated ovariectomized ewes in this study appears to be in disagreement with the previous report in which cortisol was depressed in cycling ewes exposed to heat stress (Sheikheldin, 1987). The lack of effect of exposure to cyclic temperature on cortisol was also reported for cattle subjected to temperature settings lower than in the present investigation (Shayanfar et al., 1975). The variance of the present results with the previous report might have resulted from insufficient number of samples to establish significant differences in this investigation.

In agreement with earlier findings (De Silva et al., 1983; Benhaj \& Cooke, 1985), the present results show that the adrenals secrete progesterone. However, in saline-injected ovariectomized ewes, progesterone was not elevated during heat stress as compared to values seen during the preovulatory period (following regression of the CL) in cycling ewes. After regression of the CL in the cycling ewes progesterone concentration was not influenced by cyclic heat stress. Therefore, although the adrenals are a second source of progesterone secretion in the ewe, they do not appear to increase their progesterone secretion in response to cyclic heat stress and stress-induced elevation in progesterone probably represents increased luteal secretion of progesterone.

The results also confirm earlier reports that a dose of exogenous ACTH, in ovariectomized ewes, sufficient to elevate cortisol significantly, will also elevate progesterone (De Silva et al., 1983; Benhaj \& Cooke, 1985). In addition, the present results show that the secretory profiles of both cortisol and progesterone, in response to $\mathrm{ACTH}$, followed a biphasic trend during cyclic heat stress, which might have been due to a transient lack of steroidogenic precursors.

In conclusion, this study provides no evidence that cyclic heat stress elevates adrenal progesterone output. Even when the adrenal is stimulated by exogenous ACTH the peripheral concentration of progesterone achieved is relatively low, not rising above that observed during the onset of the preovulatory gonadotrophin surges in cycling ewes (Sheikheldin, 1987). Therefore, based on these findings, the involvement of adrenal progesterone secretion in inhibiting the release of gonadotrophins is doubtful during cyclic heat stress.

We thank Mrs L. Mollison for the assistance during sampling; Dr N. C. Rawlings for the progesterone and cortisol antibodies; and Dr R. J. Parker and Dr G. H. Crow for statistical advice. This investigation has been partly supported by the Natural Sciences and Engineering Research Council of Canada (grant A6472 to B.E.H. and grant A6251 to W.M.P.) and by the University of Gezira (Sudan) scholarship to M.A.S.

\section{References}

Abilay, T.A., Johnson, H.D. \& Madan, M. (1975) Influence of environment heat on peripheral plasma progesterone and cortisol during the bovine estrous cycle. J. Dairy Sci. 58, 1836-1848.

Abraham, G.E. (1974) Radioimmunoassay of steroids in biological materials. Acta endocr., Copenh., Suppl. $183,3-42$.
Abraham, G.E., Swerdloff, R., Tulchinsky, D. \& Odell, W.D. (1971) Radioimmunoassay of plasma progesterone. J. clin. Endocr. Metab. 32, 619-624.

Alvarez, M. B. \& Johnson, H.D. (1973) Environmental heat exposure on cattle plasma catecholamine and glucocorticoids. J. Dairy Sci. 56, 189-194.

Benhaj, K.M. \& Cooke, R.G. (1985) Adrenal responses 
to ACTH in sheep. J. Endocr. 107, Suppl. 1, Abstr. 34.

Bjersing, L., Hay, M.F., Kann, G., Moor, R.M., Naftolin, F., Scaramuzzi, R.J., Short, R.V. \& YoungLai, E.V. (1972) Changes in gonadotropins, ovarian steroids and follicular morphology in sheep at oestrus. $J$. Endocr. 52, 465-479.

Christison, G.I. \& Johnson, H.D. (1972) Cortisol turnover in heat-stressed cows. J. Anim. Sci. 35, $1005-1010$.

Cleveland, W.S. (1979) Robust locally weighted regression and smoothing scatterplots. J. Am. Stat. Assoc. 74, 829-836.

De Silva, M., Kaltenbach, C.C. \& Dunn, T.G. (1983) Serum cortisol and progesterone after administration of adrenocorticotropin and (or) prolactin to sheep. $J$. Anim. Sci. 57, 1525-1529.

Ekins, R.P. (1974) Radioimmunassay and saturation analysis. Basic principles and theory. Br. med. Bull. 30, 3-11.

Howland, B.E., Palmer, W.M., Sanford, L.M. \& Beaton, D.B. (1978) Estrogen-induced LH and FSH release in ovariectomized ewes: effect of season. Can. J. Anim. Sci. 58, 541-551.

Merriam, G.R. \& Wachter, K.W. (1982) Algorithms for the study of episodic hormone secretion. Am. J. Physiol. 243, E310-E318.

Pant, H.C., Hopkinson, C.R.N. \& Fitzpatrick, R.J. (1977) Concentration of oestradiol, progesterone, luteinizing hormone and follicle stimulating hormone in the jugular venous plasma of ewes during the oestrous cycle. J. Endocr. 73, 247-255.

Rahe, C.H., Owens, R.E., Fleeger, J.L., Newton, H.J. \& Harms, P.G. (1980) Pattern of plasma luteinizing hormone in the cyclic cow: dependence upon the period of the cycle. Endocrinology 107, 498-503.
Rawlings, N. \& Ward, W.R. (1978) Correlations of maternal and fetal endocrine events with uterine pressure changes around parturition in the ewe. $J$. Reprod. Fert. 54, 1-8.

Rodbard, D., Rayford, P.L., Cooper, J.A. \& Ross, G.T. (1968) Statistical quality control of radioimmunoassay. J. clin. Endocr. Metab. 28, 1412-1418.

Rodbard, D., Bridson, W. \& Rayford, P.L. (1970) Rapid calculation of radioimmunoassay results. J. Lab. clin. Med. 74, 770-781.

Roussel, J.D., Beatty, J.F. \& Lee, J.A. (1977) Influence of season and reproductive status on peripheral plasma progesterone levels in the lactating bovine. Int. J. Biometeor. 21, 85-91.

SAS User's Guide, Statistics. (1982) Statistical Analysis System Institute Inc., Cary, N.C.

Shayanfar, F., Head, H.H., Wilcox, C.L. \& Thatcher, W.W. (1975) Adrenal responsiveness in lactating Holstein cows. J. Dairy Sci. 58, 870878.

Sheikheldin, M.A. (1987) The effect of heat stress on the estrous cycle and hormone concentration in sheep. Ph.D. thesis, University of Manitoba.

Snedecor, G.W. \& Cochran, W.G. (1967) Statistical Methods, 6th edn. Iowa State University Press, Ames.

Wheeler, A.G. \& Blackshaw, A.W. (1986) Effect of cold and hot ambient temperatures on plasma progesterone concentrations in ewes with intact and denervated ovaries containing experimentally maintained corpora lutea. J. Reprod. Fert. 78, 353-360.

Wold, S. (1974) Spline functions in data analysis. Technometrics 16, $1-11$.

Yuthasastrakosol, P., Howland, B.E., Simaraks, S. \& Palmer, W.M. (1974) Estrogen-induced LH release in progesterone treated ovariectomized ewes. Can. J. Anim. Sci. 54, 565-572.

Received 26 February 1988 